\title{
Regional Human Rights Bodies (2019)
}

\author{
Emanuele Sommario*
}

\section{Introduction}

Natural and human-made disasters clearly have the potential to affect the full enjoyment of human rights. ${ }^{1}$ In addition to their specific obligations under disaster law treaties, States must frame their preparedness, prevention, response and rehabilitation activities in accordance with the legal standards emerging from universal and regional human rights instruments. This section analyses normative developments relevant to disasters that occurred within different regional human rights systems during the course of 2019.

\section{Developments at the European Court of Human Rights}

An interesting judgment related to the prevention of natural disasters was issued by the European Court of Human Rights (ECtHR) in 2019. In the case Chatzigiannakou v. Greece ${ }^{2}$ the ECtHR had to rule on the failure by the Greek authorities to enforce a court decision demanding the demolition of parts of a building in Athens on account of its non-compliance with anti-seismic regulations. The applicant is a Greek national who owns a house in Athens that she acquired from her mother and grandmother in 2009. In 2000 a company began building a block of flats on land adjacent to the house. The applicant asked the Athens municipal authorities to verify certain aspects of the new construction to ensure conformity with anti-seismic regulations. The authorities discovered some defects and asked the competent regional authorities to order the discontinuance of the work and impose sanctions on the company.

On 31 October 2001 the competent regional office decided to abide by the indication of the municipal authorities and gave the company a deadline to bring the construction into conformity with anti-seismic regulations. That decision became final but the necessary work was never completed by the

\footnotetext{
* Assistant Professor of International Law, Scuola Superiore Sant'Anna, Pisa.

1 See Walter Kälin, 'The Human Rights Dimension of Natural or Human-Made Disasters', (2012) 55 German Yearbook of International Law, 119-147.

2 ECtHR, Chatzigiannakouv. Greece, Judgment of 18 July 2019 (the full text of the ruling is only available in French).
} 
company even though the deadline had expired. In September 2002 the applicant's mother asked the Secretary General for the Attica Region to take all the necessary measures to enforce the decision of 31 October 2001, namely the mandatory evacuation of the flats in the building and the immediate demolition of the parts which were deemed to be unsafe. Following the tacit rejection of her request, the applicant's mother appealed to the Supreme Administrative Court. Meanwhile Ms Chatzigiannakou had become the owner of the building and replaced her mother in the proceedings.

On 7 March 2012 the Supreme Administrative Court declared Ms Chatzigiannakou's appeal inadmissible. It noted that the 31 October 2001 decision had become final but had not been enforced. It was of the view, however, that the authorities' failure to enforce the decision was not subject to an administrative appeal. Relying on Article 1 of Protocol No. 1 (protection of property) to the Convention, the applicant complained that the planning authorities' failure to enforce the 31 October 2001 decision had put her house at risk of serious damage and had diminished its value. The decision had ordered that the building be brought into conformity with anti-seismic norms, and failure to comply should have led to the demolition of the unsafe parts of the building. The fact that the decision was not enforced constituted an unjustified interference in the applicant's right to property. ${ }^{3}$

The Court found that the responding State was indeed responsible for unduly limiting Ms Chatzigiannakou's property rights. The judgment recalls that the wording of Article 1 Protocol 1 insists several times that limitations on the established rights have to be provided for by law. This reflects the idea that the rule of law permeates the totality of the rights enshrined in the ECHR and even public authorities must be subject to it in order to uphold what is one of the fundamental principles of a democratic society. ${ }^{4}$ In the present case, the Court noted that the authorities had been aware of the illegality of the conduct of the construction company and had called for measures to be taken to rectify the situation. They had then recorded the failure to implement those measures, while acknowledging that they were powerless to ensure enforcement. Even the Supreme Administrative Court took the view that the non-enforcement fell outside of its remit. ${ }^{5}$ Lastly, Ms Chatzigiannakou's inability to obtain the enforcement of an administrative decision - of which the relevance and validity had never been challenged and which had significant repercussions for her property - had thus upset the fair balance between the

3 Ibid., paras. 27 and 41 .

4 Ibid., para. 45 .

5 Ibid., para. 53 . 
requirements of the general interest of the community and the imperatives of safeguarding individual rights. ${ }^{6}$ There had thus been a violation of the applicant's right to property. ${ }^{7}$

While the outcome of the case was not unexpected, the reasoning of the Court is perhaps less obvious. The judges claimed that they would verify whether the balance between collective interests and individual rights had been upheld, ${ }^{8}$ yet they failed to point out what the specific collective interest at stake was. At the same time, no reference was made to the positive obligations of the State in protecting the rights to life and property from foreseeable threats. As known, ECtHR case law has established that an effective exercise of the right to property does not depend merely on the State's duty not to interfere, but may require positive measures of protection, particularly where there is a direct link between the measures an applicant may legitimately expect from the authorities and his effective enjoyment of his possessions. ${ }^{9}$ While the scope of the positive obligations owed by States is less wide in the case of the right to property than it is vis-à-vis absolute rights (such as the right to life), a certain degree of due diligence is nonetheless required to protect the right to the peaceful enjoyment of possessions, even though it 'cannot extend further than what is reasonable in the circumstances'. ${ }^{10}$ The measures to be adopted and their timing obviously also depend on the imminence and the seriousness of the risk. ${ }^{11}$

Admittedly, in the Chatzigiannakou case there was no concrete indication that an earthquake was about to occur, so the risk to the applicant's house could not have been considered to be immediate and did not require instant action. ${ }^{12}$ However, the judgment refers to earthquakes as being 'very frequent' in Greece $^{13}$ and as having considerable destructive potential if they impact

$6 \quad$ Ibid., para. 55 .

7 The Court also found that the applicant was deprived of an effective remedy in violation of Article 13 of the ECHR. The remedy offered by the Greek Civil Code Implementation Act only allowed material compensation in cases of illegal conduct by public authorities. This purely compensatory relief had not enabled the applicant to make an effective complaint and have the decision to demolish the dangerous parts of the building, ibid., para. 6o.

$8 \quad$ Ibid., para. 49 .

9 ECtHR, Önerylldız v. Turkey [GC], Judgment of 30 November 2004, para. 134.

10 ECtHR, Budayeva and others v. Russia, Judgment of 20 March 2008, para. 175.

11 Mirko Sossai, 'States' Failure to Take Preventive Action and to Reduce Exposure to Disasters as a Human Rights Issue' in Zorzi Giustiniani et al (eds.), Routledge Handbook of Human Rights and Disasters (Routledge 2018) 124-127.

12 Öneryıldız v. Turkey [GC], para. 101.

13 Chatzigiannakou v. Greece, para. 41. 
on densely populated areas. In Budayeva the ECtHR determined that in the sphere of emergency relief and mitigation of natural hazards, State obligations are more demanding if the risk 'concerned a recurring calamity affecting a distinct area developed for human habitation or use.'. ${ }^{14}$ In such cases, "[t]he scope of the positive obligations imputable to the State in the particular circumstances would depend on the origin of the threat and the extent to which one or the other risk is susceptible to mitigation.'. ${ }^{15}$ It is submitted that the risk affecting the applicant's house was not only susceptible to mitigation, but that the required measures had actually already been identified by the Greek authorities, which, however, failed to implement them. In sum, the Court could perhaps have based its findings of responsibility not only on a clear breach of the rule of law, but also on a failure by the respondent State to live up to its positive obligations to protect the applicant's right to property.

\section{3}

\section{Developments within the African Human Rights System}

Another insightful resolution relevant to the prevention of and response to natural disasters was issued by the African Commission on Human and People's Rights (ACHPR) in May 2019. In March and April 2019, South-East Africa was hit by two subsequent cyclones that left a trail of destruction in their path and close to 2.2 million people in need urgent assistance in Mozambique alone. ${ }^{16}$ On the night of 14 to 15 March Tropical Cyclone Idai hit central Mozambique. The cyclone brought torrential rains and winds to many of the country's provinces. It then continued across land as a tropical storm and hit eastern Zimbabwe with heavy rains and strong winds. The heavy rainfall and the ensuing flash flooding resulted in deaths, destruction of livelihoods and properties. Idai left more than 600 people dead and an estimated 1.85 million people in need of assistance in Mozambique alone. On the evening of 25 April, Tropical Cyclone Kenneth reached Northern Mozambique. With wind gusts of up to $220 \mathrm{~km} / \mathrm{h}$, it was the strongest cyclone to have ever hit the African continent. Cyclone Kenneth left 374.000 people in need and killed 38 people in Mozambique alone. Nearly 35.0oo houses were either partially or totally

\footnotetext{
14 Budayeva and others v. Russia, para. 137.

15 Ibid.

16 UN Office for the Coordination of Humanitarian Affairs, Cyclones Idai and Kenneth, $<$ https://www.unocha.org/southern-and-eastern-africa-rosea/cyclones-idai-and -kenneth $>$ last accessed (as any subsequent URL) on 27 July 2020.
} 
destroyed. Social service infrastructure was also hard-hit, with many schools and health facilities being either destroyed or heavily affected. The cyclone also ravaged several islands of the Comoros archipelago. ${ }^{17}$

These events prompted the ACHPR to adopt a 'Resolution on the Human rights impacts of extreme weather in Eastern and Southern Africa due to climate change.'18 The text contains many recommendations to State parties to the African Union (AU), urging them to address climate change and its consequences. The preamble makes explicit reference to the African Union Convention for the Protection and Assistance of Internally Displaced Persons in Africa (Kampala Convention), ${ }_{19}^{19}$ which requires State Parties to take measures to protect and assist persons who have been internally displaced due to natural or human made disasters. ${ }^{20}$ The Convention is one of the few treaties explicitly including the victims of disasters among its beneficiaries.

The Resolution urges the affected states to ensure that the rights of affected individuals and communities are protected, placing special emphasis on vulnerable groups who are more exposed to the risk of further violations that may result from a lack of security and the collapse of basic infrastructures. ${ }^{21}$ In particular, women and girls are singled out as particularly exposed to risks of sexual violence and abuse, especially in relation to access to humanitarian assistance and other basic necessities. The text also invites African States and the whole international community to provide cross-border emergency relief to the affected areas and to mobilise resources aimed at the reconstruction and rehabilitation of the livelihoods of affected individuals. ${ }^{22}$

17 Reliefweb, Tropical Cyclone Kenneth (April 2019), <https://reliefweb.int/disaster/ tc-2019-000038-moz?primary_country=65\#content>.

18 ACHPR, Resolution 417 (LXIV) 2019 (14 May 2019), available at <https://www.achpr.org/ sessions/resolutions?id $=441>$.

19 African Union Convention for the Protection and Assistance of Internally Displaced Persons in Africa (Kampala Convention) (23 October 2009). The Convention has currently ${ }_{31}$ State parties, while another nine African Union States have signed it. The text is available at <https://au.int/en/treaties/african-union-convention-protection-andassistance-internally-displaced-persons-africa $>$.

20 See Mike Asplet and Megan Bradley, 'Introductory Note to the African Union Convention for the Protection and Assistance of Internally Displaced Persons in Africa (Kampala Convention)', (2013) 52 International Legal Materials, 397-410; and Flavia Zorzi Giustiniani, 'New Hopes and Challenges for the Protection of IDPs in Africa: The Kampala Convention for the Protection and Assistance of Internally Displaced Persons in Africa', (2011) 39 Denver Journal of International Law and Policy, 347-370.

21 Resolution 417 (LXIV) 2019, para. 4.

22 Ibid., para. 6. 
The Resolution also urges AU Member States to accelerate the process of creation and operationalisation of the African Humanitarian Agency (AfHA). The creation of the Agency was decided by the Assembly of the AU in 2016, ${ }^{23}$ recommending that the new entity 'should be anchored on regional and national mechanisms and funded with Africa's own resources. ${ }^{24}$

Once it is operative, the AfHA is expected to fill a major gap in humanitarian action in Africa by providing, as its primary mandate, an effective coordination effort in the management of humanitarian crises on the African Continent. This would involve contributions at the strategic level as well as gathering, systematising and sharing best practices among AU Member States, bearing in mind that the latter have the ultimate responsibility for the protection of individuals either directly or through regional mechanisms. The AfHA is expected to have an effective ground presence in humanitarian operations, always acting in close cooperation with Member States. In substance, the Agency is meant to become the African Union's humanitarian assistance tool and should be activated whenever States that face situations of crisis request its intervention. ${ }^{25}$ The AU has commissioned a study ${ }^{26}$ on the operationalisation of the Agency that will be discussed by the AU Assembly of Member States in 2020. More on the Agency's future will be reported in next year's edition of this review. Yet, the project already faces concrete challenges which will require a strong political will to be properly addressed. ${ }^{27}$

Within the Inter-American System, a press release issued by the InterAmerican Commission on Human Rights (IACHR) is worth highlighting. On 25 January 2019, a mining dam that sat above Brumadinho, a large town in

\footnotetext{
23 See Decision Assembly/AU/Dec.6o4 (Xxvi) (30 January 2016).

24 Ibid., para. 9(ii).

25 African Union, Press Release No. 054/2019, 'Member States Experts meeting on the operationalisation of the African Humanitarian Agency opens', (15 April 2019) available at $<$ https://au.int/en/pressreleases/20190415/member-states-experts-meet ing-operationalisation-african-humanitarian-agency>.

26 Babafemi Adesina Badejo, 'Study on the modalities for the operationalization of an African Humanitarian Agency', (21 October 2019) available at <https://au.int/sites/ default/files/newsevents/reports/385oo-rp-pa26393_e_original.pdf >

27 See Oheneba Boateng, 'Three challenges for the African Union's new humanitarian agency', The New Humanitarian, (28 August 2019) available at $<$ https://www.thenewhumanitar ian.org/opinion/2019/o8/28/African-Union-humanitarian-agency-three-challenges>.
} 
south-eastern Brazil, collapsed and unleashed a tidal wave of waste and mud that engulfed homes, businesses and residents in its path. It killed at least 157 people while 182 persons went missing. ${ }^{28}$ According to the available public information, the dam had a volume of 12.7 million cubic meters of toxic waste, which reached the Vila Ferteco community. The structure, owned by the giant Brazilian mining company Vale, strained the very definition of "dam": it was an enormous reservoir of mining waste held back by little more than walls of sand and silt with no separate concrete or metal barriers to confine its contents.

The Brumadinho tailings dam disaster is not a one-off tragic accident. This was the second tailings dam collapse to happen in Brazil in just over three years. In November 2015, in the nearby city of Mariana, millions of tonnes of toxic waste swept through the Rio Doce, devastating communities in its wake. Nineteen people were killed in the tragedy and the mine was again owned by Vale.

In view of these events, the IACH R and its Special Rapporteur on Economic, Social, Cultural and Environmental Rights (SRESCER) ${ }^{29}$ expressed their deep sorrow and solidarity towards all victims and affected communities, as well as their concern for the magnitude of the tragedy in human, environmental and labour terms. ${ }^{30}$ They also urged the Brazilian authorities and the company involved to take all necessary measures to mitigate and prevent the aggravation of environmental damage and to facilitate mechanisms of reparation for victims and their families. In its press release the IACHR stressed that, in the absence of urgent and appropriate measures, the consequences of the disaster could be irreversible due to the negative impact that the contamination of the soil and water by heavy metals generates and the high risks posed to the health of the people affected by the accident.

The IACHR's statements draw heavily on the recent Advisory Opinion by the Inter-American Court of Human Rights (IACtHR) on the relationship between the environment and human rights. ${ }^{31}$ There the Court stated that " $[\mathrm{i}] \mathrm{n}$ the

28 New York Times, 'Why Did the Dam in Brazil Collapse? Here's a Brief Look' (9 February 2019) available at <https://www.nytimes.com/2019/o2/o9/world/americas/brazil-dam-disaster .html>.

29 The SRESCER is an Office of the IACHR, specially created in 2017 to support the Commission in fulfilling its mandate to promote and protect economic, social, cultural and environmental rights in the Americas, see <http://www.oas.org/en/iachr/desc/>.

30 IACHR, Press Release N. o19/19, 'Special Rapporteurship ESCER of the IACHr expresses deep concerns about human, environmental and labor tragedy in Brumadinho (Minas Gerais, Brazil), and calls for the integral reparations for victims' (30 January 2019) available at <https://www.oas.org/en/iachr/media_center/PReleases/2019/o19.asp >.

31 IACtHR, Advisory Opinion OC-23/17 as requested by the Republic of Colombia, 'The Environment and Human Rights' (15 November 2017) IACtHR Ser A No 23. 
framework of environmental protection, the international responsibility of the State derived from the conduct of third parties may result from the lack of regulation, supervision or oversight of the activities of these third parties that cause harm to the environment'. ${ }^{22}$ The IACtHR recalled that the State has a duty to protect persons within its territory or jurisdiction against all human rights violations committed by third parties, including companies. ${ }^{33}$ Consequently, States must adopt the appropriate measures to regulate, prevent, investigate, punish and ensure access to effective mechanisms for reparation for these abuses through appropriate policies, regulatory activities and by activating legal proceedings against the companies involved. ${ }^{34}$ The IACH R and its SRESCER also stress that companies must respect human rights not only by refraining from infringing on them but by exercising due diligence in matters of human rights, for example by evaluating in advance the risks that their productive or commercial activity may generate on human rights, including the environment; ${ }^{35}$ by adopting adequate prevention measures; and by responding to the negative impacts and violations of human rights that business activities may cause or contribute to.

The press release then urges Brazil to activate emergency plans, which include mitigation, cleaning and restoration actions in the affected area, taking into account the highest international standards of care for this type of disaster, in order to avoid causing greater damages affecting the health of the people and the ecosystem. ${ }^{36}$ In addition, measures must be taken to: guarantee labour rights, in particular those on occupational health and safety; make every effort to locate the whereabouts of the disappeared persons; and ensure that all the victims of the catastrophe and their families have access to comprehensive reparation, ${ }^{37}$ including medical, psychological and humanitarian assistance.

Furthermore, considering that Brazil has recently signed the Regional Agreement on Access to Information, Public Participation and Access to

\footnotetext{
$32 \quad$ Ibid., para. 119.

33 Ibid., para. 118.

34 Ibid., para. 154.

35 Ibid., para. 16o.

36 Again, similar obligations were identified by the IACtHR in its 2017 Advisory Opinion, para. 172 .

37 Ibid., paras. 236-236. Here the Court emphasises the relevance of the right to access to justice (which may include remedies and reparations) for the victims of human rights violations that may result from failure to comply with environmental standards.
} 
Justice in Environmental Matters, ${ }^{38}$ the State should take into account its provisions while responding to the present situation, even though the instrument is not yet in force. ${ }^{39}$

38 Regional Agreement on Access to Information, Public Participation and Justice in Environmental Matters in Latin America and the Caribbean (4 March 2018). See Marlies Hesselman, 'International Environmental Law (2018)', (2019) 1 Yearbook of International Disaster Law, 443-444. For more details on the agreement, see Stephen Stec and Jerzy Jendrośka, 'The Escazú Agreement and the Regional Approach to Rio Principle 10: Process, Innovation, and Shortcomings', (2019) 31 Journal of Environmental Law, 533-545.

39 In accordance with article 22(1), the agreement shall enter into force on the ninetieth day after the date of deposit of the eleventh instrument of ratification. As of May 2020, the treaty has received nine ratifications. 